TITLE:

\title{
Electrodeposition of Zn-Al Alloys from AlCl-ZnCl-Dimethilsulfone Molten Electrolytes
}

\section{$\operatorname{AUTHOR}(\mathrm{S}):$}

Takenaka, Kazumi; Mizuta, Yuji; Hirato, Tetsuji

\section{CITATION:}

Takenaka, Kazumi ... [et al]. Electrodeposition of Zn-Al Alloys from AlCI-ZnCl-Dimethilsulfone Molten Electrolytes. ECS Transactions 2010, 25(29): 169-173

ISSUE DATE:

2010

URL:

http://hdl.handle.net/2433/237617

\section{RIGHT:}

(c) The Electrochemical Society, Inc. 2010. All rights reserved. Except as provided under U.S. copyright law, this work may not be reproduced, resold, distributed, or modified without the express permission of The Electrochemical Society (ECS). The archival version of this work was published in 'ECS Trans. 2010 volume 25, issue 29, 169-17'.; この論文は出版 社版でありません。引用の際には出版社版をご確認ご利用ください。; This is not the published version. Please cite only the published version. 


\title{
Electrodeposition of $\mathrm{Zn}$-Al alloys from $\mathrm{AlCl}_{3}-\mathrm{ZnCl}_{2}$-Dimethilsulfone Molten Electrolytes
}

\author{
K. Takenaka, Y. Mizuta and T. Hirato \\ Department of Energy Science and Technology, Kyoto University, Kyoto, 606-8501, \\ JAPAN
}

The electrodeposition of $\mathrm{Zn}-\mathrm{Al}$ alloys was investigated using $\mathrm{AlCl}_{3}-\mathrm{ZnCl}_{2}$-dimethylsulfone $\left(\mathrm{DMSO}_{2}\right)$ molten electrolytes at $110^{\circ} \mathrm{C}$. The alminum contents of electrodeposites obtained at constant current densities between 30 and $100 \mathrm{~mA} / \mathrm{cm}^{2}$ ranged from 1 to 8 at\%. With the decrease in $\mathrm{ZnCl}_{2}$ concentrations of the electrolyte and with the increase in current densities, the intensity of the diffraction peaks of $\mathrm{Zn}$ decreased suggesting low crystallinity of zinc. Electrodeposition was carried out at constant potentials from $-0.8 \mathrm{~V}$ to $-1.5 \mathrm{~V}$ vs $\mathrm{Zn}$ in $\mathrm{DMSO}_{2} / \mathrm{ZnCl}_{2}$, on the basis of the cyclic voltammogram, and deposits with $\mathrm{Al}$ contents ranging from 1-90 at\% were obtained.

\section{Introduction}

Zinc coating is used to galvanize steel to prevent corrosion by forming a physical barrier, and by acting as a sacrificial anode. In recent years, a strong demand for zinc, especially in China, has led to a rising zinc price. Furthermore, zinc supply is not guaranteed in future because of the drain on natural zinc resources; therefore, the development of a new technique which reduces zinc consumption is desired. A possible alternative material to zinc is aluminum, since it has high corrosion resistance and is relatively abundant; however, aluminum is not sufficient as a sacrificial anode. Al-Zn alloy coating is therefore attractive, because it may show high corrosion resistance due to aluminum and act as a sacrificial anode due to zinc. At the present time, Al-Zn alloy coating is made by hot dipping. If Al-Zn coating can be formed by electroplating, the coating can be thinner, reducing zinc consumption, and can be applied to a body with a complicated shape.

Aluminum and some of its alloys can be electrodeposited from an $\mathrm{AlCl}_{3}-\mathrm{NaCl}$ molten salt. The attractiveness of this molten salt is linked to its low cost and a reasonably low working temperature. The drawbacks are its high $\mathrm{AlCl}_{3}$ vapor pressure and the fact that the melt is very corrosive. Non-aqueous, solvent-based electrolytes are an alternative. Recently, a new electrolyte for aluminum deposition based on $\mathrm{AlCl}_{3} /$ dimethylsulfone $\left(\mathrm{DMSO}_{2}\right)$, was introduced (1-3). This electrolyte has much lower $\mathrm{AlCl}_{3}$ vapor pressure as compared to the $\mathrm{AlCl}_{3}-\mathrm{NaCl}$ molten salt and a reasonable cost. Also, this electrolyte yield aluminum deposits exhibiting a fine grain size, have a relatively smooth surface appearance and, a high purity.

In this work, $\mathrm{Zn}-\mathrm{Al}$ alloy deposition from $\mathrm{AlCl}_{3} / \mathrm{ZnCl}_{2} / \mathrm{DMSO}_{2}$ was investigated. The effect of the bath composition, current density and cathode potential on the deposit was examined. 


\section{Experimental}

Anhydrous aluminum chloride, $\mathrm{AlCl}_{3}$, (Fluka) was used in the as-received state. Zinc chloride, $\mathrm{ZnCl}_{2}$ (Nacalai Tesque), was heated to $200{ }^{\circ} \mathrm{C}$ for $24 \mathrm{~h}$ to remove the water. Dimethylsulfone, $\mathrm{DMSO}_{2}$, (Fluka) was dried at $40{ }^{\circ} \mathrm{C}$ for $24 \mathrm{~h}$ in a dry glove box filled with argon. A glass vessel with a silicon rubber lid was used as an electrolytic cell. Electrolytes were prepared in the dry glove box by mixing $150 \mathrm{~g}$ of $\mathrm{DMSO}_{2}$ with the appropriate amounts of $\mathrm{AlCl}_{3}$ and $\mathrm{ZnCl}_{2}$ at ambient temperature in the glass cell. The anode was a zinc plate of $99.99 \%$ purity. The cathode was a copper plate covered with PTFE tape to expose a known area $(10 \mathrm{~mm} \times 10 \mathrm{~mm})$ to the solution.

Cyclic voltammetry of the solutions was performed with a three-electrode method using an electrochemical analyzer (ALS 660C). A zinc wire immersed in $\mathrm{ZnCl}_{2} / \mathrm{DMSO}_{2}$ with the mol ratio of $1 / 10$ was used as reference. The voltammograms were obtained by scanning the potential of the working electrode at a constant scan rate of $0.02 \mathrm{~V} \mathrm{~s}^{-1}$. A glassy carbon was employed for the working electrode.

Deposition experiments were performed galvanostatically and potentiostatically at $110{ }^{\circ} \mathrm{C}$ in electrolytes with a mole ratio of $\mathrm{AlCl}_{3} / \mathrm{DMSO}_{2}=1.5 / 10$ with the addition of an adequate amount of $\mathrm{ZnCl}_{2}$. The deposition amount was $120 \mathrm{C} \mathrm{cm}^{-2}$. X-ray diffractometry (XRD) of deposits was performed with a $\mathrm{Cu}-\mathrm{K} \alpha$ source.

\section{Results and Discussion}

\section{$\underline{\text { Galvanostatic deposition }}$}

Electrodeposition experiments were conducted using baths with the mol ratio of $\mathrm{ZnCl}_{2} / \mathrm{AlCl}_{3}$ from $0.1 / 1.5$ to 0.3 / 1.5, at current densities from $30 \mathrm{~mA} \mathrm{~cm}^{-2}$ to $100 \mathrm{~mA}$ $\mathrm{cm}^{-2}$. Dendrite deposition was observed at the frame part of deposition area in the all experiments. Dendrite deposition was more marked at lower $\mathrm{ZnCl}_{2}$ content and at higher current densities. At center parts of the deposits, the relatively smooth surface was obtained. In the following discussion, we will mention about this center part of deposits.

Figure 1 shows SEM images of the deposits obtained at a current density of $30 \mathrm{~mA}$ $\mathrm{cm}^{-2}$ using baths with different composition. Zinc crystals were observed. The crystal size decreased and the $\mathrm{Al}$ content in the deposits increased with increasing $\mathrm{ZnCl}_{2}$ concentration in the electrolytes.

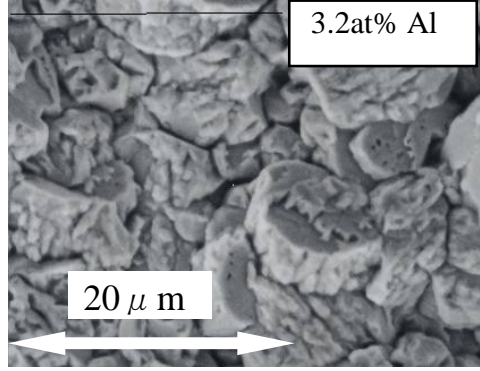

(a) $\mathrm{AlCl}_{3} / \mathrm{ZnCl}_{2}=1.5 / 0.1$

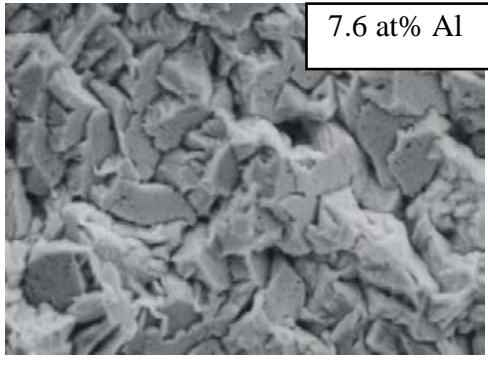

(b) $\mathrm{AlCl}_{3}: \mathrm{ZnCl}_{2}=1.5 / 0.2$

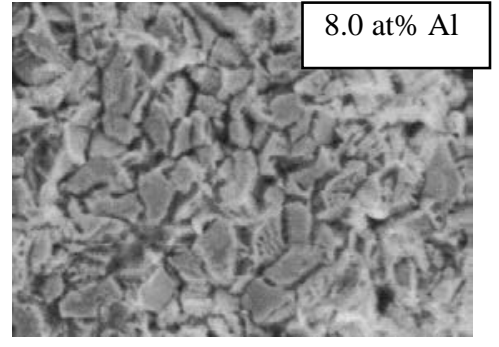

(c) $\mathrm{AlCl}_{3} / \mathrm{ZnCl}_{2}=1.5 / 0.3$

Figure 1 SEM images and $\mathrm{Al}$ content of the deposits obtained at a current density of 30 $\mathrm{mA} \mathrm{cm} \mathrm{cm}^{-2}$ 
Figure 2 depicts SEM images and XRD results of the deposits obtained at different current densities using the bath with the mol ratio of $\mathrm{DMSO}_{2} / \mathrm{AlCl}_{3} / \mathrm{ZnCl}_{2}=10 / 1.5 / 0.1$. With the deposits obtained at $30 \mathrm{~mA} \mathrm{~cm}^{-2}$, diffraction peaks of zinc were recognized, though none of $\mathrm{Al}$ was recognized, and zinc crystals observed clearly in the SEM images. On the other hand, in the XRD pattern of the deposits obtained at 40 and $100 \mathrm{~mA} \mathrm{~cm}{ }^{-2}$, any diffraction peak except for those of cupper substrate was not recognized. These results suggest that aluminum deposited in zinc matrix, being supersuturated in Zn solid solution and/or formed a $\mathrm{Zn}-\mathrm{Al}$ amorphous phase.
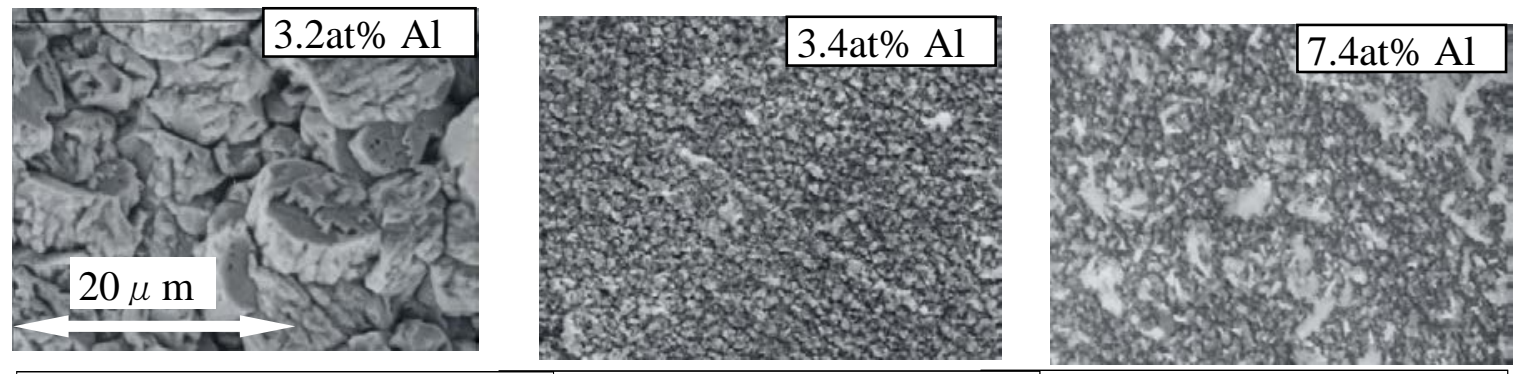

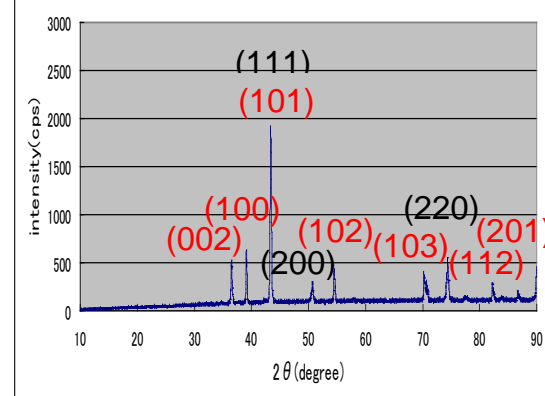

(a) $30 \mathrm{~mA} / \mathrm{cm} 2$

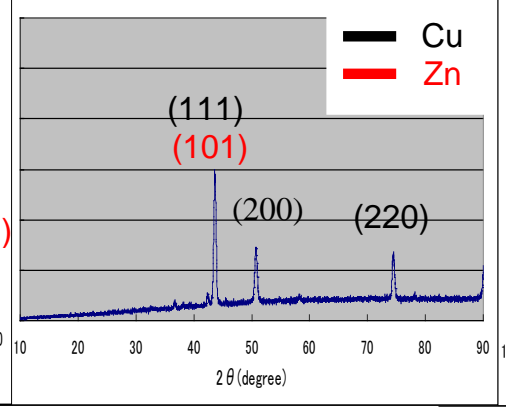

(b) $40 \mathrm{~mA} / \mathrm{cm} 2$

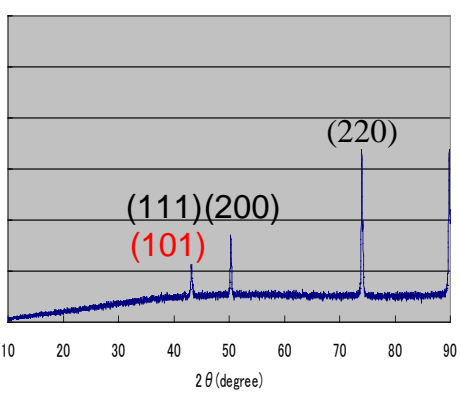

(c) $100 \mathrm{~mA} / \mathrm{cm} 2$

Figure 2 SEM images and XRD of the deposits obtained at different current densities using the molten electrolytes with the mol ratio of $\mathrm{DMSO}_{2} / \mathrm{AlCl}_{3} / \mathrm{ZnCl}_{2}=10 / 1.5 / 0.1$.

\section{$\underline{\text { Potentiostatic deposition }}$}

$\mathrm{Zn}-\mathrm{Al}$ alloy deposits were obtained by galvanostatic electrolysis from $\mathrm{AlCl}_{3} / \mathrm{ZnCl}_{2}=$ 1.5/0.1 0.3 electrolytes. Aluminum contents of the deposits ranged from 1 to 8 at\%. To increase $\mathrm{Al}$ contents, electrodeposition experiments were conducted using baths with lower concentration of $\mathrm{ZnCl}_{2}$, but dendrite formation was too significant to obtain uniform deposits. Therefore, potentiostatic deposition was attempted. To determine deposition potentials, cyclic voltammetry was performed. Figure 3 shows the cyclic voltammogram for the molten electrolytes with the mol ratio of $\mathrm{DMSO}_{2} / \mathrm{AlCl}_{3} / \mathrm{ZnCl}_{2}=$ 10/1.5/0.01 at $110{ }^{\circ} \mathrm{C}$. The cathodic current increased at the potential near zero and indicated almost a constant value to $-0.6 \mathrm{~V}$. This potential range could be attributed to the deposition of $\mathrm{Zn}$. Therefore, Al-Zn codeposition is expected to be obtained by the electrolysis at the potential lower than $-0.6 \mathrm{~V}$, because $\mathrm{Zn}$ deposition proceeds under the limiting current. 


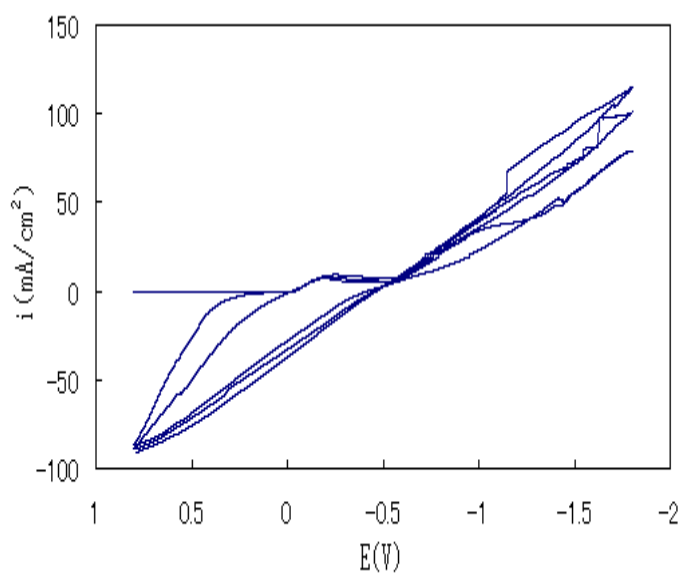

Figure 3 Cyclic voltammogram for the molten electrolytes with the mol ratio of $\mathrm{DMSO}_{2}$ / $\mathrm{AlCl}_{3} / \mathrm{ZnCl}_{2}=10 / 1.5 / 0.01$.

Electrodeposition was carried out at potentials from $-0.8 \mathrm{~V}$ to $-1.5 \mathrm{~V}$ on the basis of the cyclic voltammogram, and deposits with $\mathrm{Al}$ contents ranging from 1 - 90 at\% were obtained using a bath with a mole ratio of $\mathrm{DMSO}_{2} / \mathrm{AlCl}_{3} / \mathrm{ZnCl}_{2}=10 / 1.5 / 0.01$. Figure 4 depicts SEM images and XRD of the deposits obtained at a potential of $-1.2 \mathrm{~V}$. A relatively smooth deposit with $53 \%$ of $\mathrm{Al}$ content was obtained and diffraction peaks of zinc and aluminum were recognized.
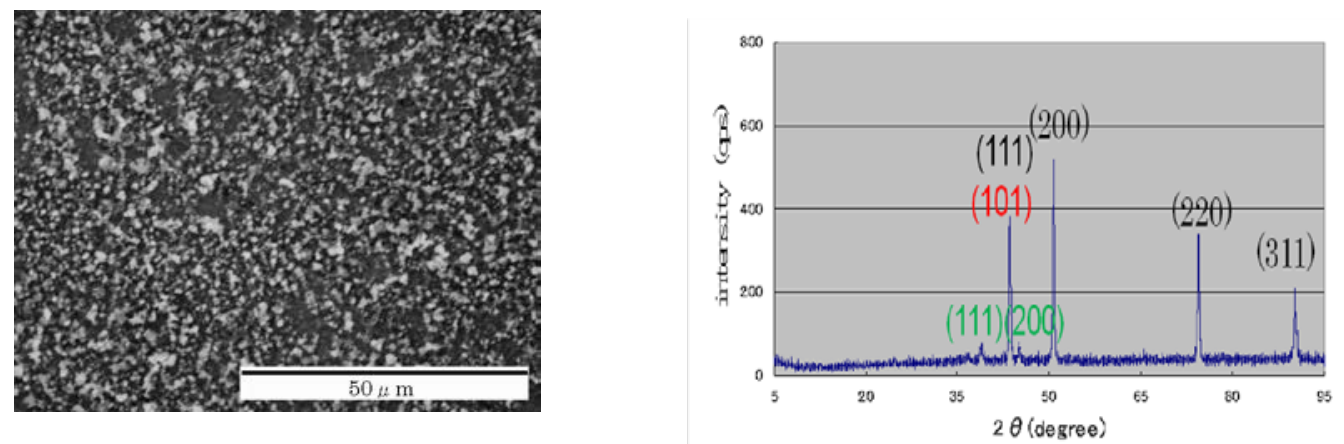

Figure 4 SEM images and XRD of the deposits obtained at a potential of $-1.2 \mathrm{~V}$ using the molten electrolytes with the mol ratio of $\mathrm{DMSO}_{2} / \mathrm{AlCl}_{3} / \mathrm{ZnCl}_{2}=10 / 1.5 / 0.01$.

\section{Conclusions}

(1)Zn-Al alloy deposits were obtained by galvanostatic electrolysis from $\mathrm{AlCl}_{3} / \mathrm{ZnCl}_{2}=$ 1.5 / 0.1 0.3 electrolytes. Aluminum contents of the deposits ranged from 1 to 8 at\%.

(2) With the decrease in $\mathrm{ZnCl}_{2}$ concentrations of the electrolyte and with the increase in current densities, the intensity of the diffraction peaks of $\mathrm{Zn}$ decreased. According to the $\mathrm{Al}-\mathrm{Zn}$ phase diagram, Al solubility in the $\mathrm{Zn}$ matrix is less than 1 at\%. It is suggested that aluminum is supersaturated in $\mathrm{Zn}$ matrix and/or that both metals form amorphous-like structures.

(3) Judging from the cyclic voltammogram, Al-Zn codeposition is expected to be obtained by the electrolysis at the potential lower than $-0.7 \mathrm{~V}$. 
(4)Electrodeposition was carried out at potentials from $-0.8 \mathrm{~V}$ to $-1.5 \mathrm{~V}$ on the basis of the cyclic voltammogram, and deposits with $\mathrm{Al}$ contents ranging from 1-90 at\% were obtained.

\section{Acknowledgments}

This work was supported by Grant-in-Aid for Scientific Research(B) (19360340).

\section{References}

1. L. Legrand, M. Heintz, A. Tranchant, and R. Messina, Electrochimica Acta, 40, 1711 (1995)

2. T. Hirato, J. Fransaer, and J-P. Celis, J. Electrochem.Soc., 148, C280 (2001).

3. J. Fransaer, E.Leunis, T. Hirato and J-P. Celis, J. Applied Electrochem., 32, 123 (2002). 